\title{
Educational Policy of the Russian Empire in the Turkistan Region (The Second Half of the XIXTH - the Beginning of the XXTH Century)
}

\author{
Anvar A. Gafarov
}

\begin{abstract}
The expansion of the Russian Empire was accompanied by a steady increase of its ethnocultural diversity. The weak integration of Russian society prompted the ruling circles to search for effective ways of the annexed people introduction to the sociocultural values that dominate in the country. The problem of acculturation was most difficult in Central Asia, annexed to Russia only in the second half of the 19 th century. School policy was recognized as the most important means of foreigner adaptation to the all-Russian cultural space. However, it had a rather differentiated character in different regions of the empire. The aim of the undertaken research is to identify the main trends in the formation and development of Russian educational policy in Turkestan, to identify its specifics and general aspects with politics in other Muslim regions. The analysis of legislative acts, paperwork, historical and ethnographic, statistical collections, periodical press materials, as well as the works of prominent adherents of foreign education allowed the author to draw a conclusion about the unity of the goal-setting principles and established traditions of state educational policy regarding the Muslim population. Its most important trend was school policy aimed at local people integration into the public education system. At the same time, the weak "development" of the Central Asian region prompted the authorities to apply more cautious forms of educational policy in comparison with other, relatively integrated parts of the country.
\end{abstract}

Keywords: Turkestan, Russian Empire, educational policy, XIXth - the beginning of XXth century.

\section{INTRODUCTION}

The accession of vast Central Asian areas (Khivan, Kokand khanate, the Bukhara emirate, etc.) in the second half of the 19th century led to a significant increase of the Muslim population in the Russian Empire. Fears of the country Islamization, the "erosion" of its sociocultural foundations contributed to the formulation of the so-called "Muslim issue". Along with the strengthening of administrative measures, the ideas of cultural assimilation ("Russification") of foreigners are actively put forward on the basis of acculturation policy. According to Russian Kulturtragers, a set of measures, including school and publishing policy, the creation of cultural and educational societies, etc., should have led to the integration of foreign population into the all-Russian sociocultural space.

The educational activity of the authorities that unfolded in Turkestan during the second half of the 19th and the beginning of the 20th centuries led to heated discussion and extensive literature, which tried to reflect modernization processes in the region adequately. While pre-revolutionary

Revised Manuscript Received on November 08, 2019.

* Correspondence Author

Anvar A. Gafarov, Kazan Federal University, Russia publications were mainly focused on finding effective ways to impose state education, the emphasis of Soviet historiography was shifted towards harsh criticism of the colonial sociocultural policy of tsarism. Current trends in the scientific understanding of the problems are largely related to the recognition that, despite the set goals, the possible assimilation and the corresponding problem of the colonized people identity, Russian cultural missionary activities have become an important factor of Muslim way of life modernization and their integration into the world system of political, economic and cultural ties [1-5 et al.].

\section{METHODS}

Based on the civilizational approach, the conceptual provisions of the Eurasian school and the theory of social modernization, as well as the comparative historical method, an attempt was made to determine the main trends of the educational policy of the Russian Empire in the Turkestan region, to identify the specifics and general aspects with similar trends with Muslim population in other regions. The sources of the research were the legislative acts, paperwork, statistical, historical and ethnographic collections, periodical press materials (Turkestan News, Turkestan native newspaper, East Review), as well as the works of prominent advocates of "foreigner" acculturation policy (Ostroumova N.P., Bobrovnikova N.A., Gramenitsky S.M. et al.), which reflected the main ideological trends in the formation and development of this trend.

\section{RESULTS AND DISCUSSION}

As the Russian influence in Central Asia was increased, the need for the experts who knew the specifics of local life, for indigenous personnel capable of serving in the native administration also increased. Initially, the illusion prevailed that there was no need to create separate schools for the education of the local population and that it was enough to have general state Russian schools. In the General Regulation on elementary schools (1864), in contrast to the initial draft and previous practice in the Caucasus and Crimea, "local dialects during first education" were not provided, since "the government should be concerned about the development of general Russian literacy, and not local dialects" [6, p. 171]. Gymnasium and gymnasium programs were compiled in the same spirit. An ardent champion of Russian public education in Turkestan, the Governor-General of the Territory Kaufman K.P. (1867-1882) sincerely believed that local religious schools are archaic, "not viable and therefore will die by themselves" with the advent of 
an alternative European education [7, p. 1]. Despite some successes $^{1}$, the opening of state schools, local Muslims stubbornly held the following opinion: "Whoever studies in a gymnasium is an infidel" [8, p. 170].

The exception was made by individual representatives of the local elite. The offspring of the Bukhara Haidarid house (Seyd-Mir-Alim, Seyd-Mir-Mansur, etc.) were trained in the military schools of Russia. The son of the Kokand khan Khudoyar Ibn-Yamin-bek studied at the Tashkent gymnasium and Teacher's seminary, the grandson - Sayyid-Nuruddin-bek was enrolled in the 2nd Orenburg Cadet Corps [9, 1888, No. 26]. The Emir of Bukhara, in commemoration of the 25th anniversary of the reign of Alexander II in 1880, even donated 20,000 rubles $^{2}$ on scholarships "to the Tashkent Men's Gymnasium for children of Bukhara natives." However, there were no children ready to enter the "junior class of the gymnasium and take the further course". ${ }^{3}$ Therefore, they decided (1885) to establish these scholarships "at the parish and city schools of the Turkestan Territory" [10, col. 28]. It was supposed to send two students to schools in Tashkent, Samarkand, Kazalinsk, Perovsk, allocating 150 rubles for each person upkeep [9, 1885, No. 28].

An attempt to establish purely Russian education among the local population was initially doomed to failure, as the main task was ethnic-cultural assimilation. According to $\mathrm{M}$. Miropiev": "Native boys, for the most part leave our schools without completing the training course, with extremely poor knowledge of Russian, Russian grammar and the Russian people; and adults still partly fear the Russian school, and partly do not expect any benefit from it" [11]. "Russification policy" for Miropiev (and others) is a fundamental principle of public education; he should "follow the example of the Kazan school system and adhere to Orthodox propaganda", ignoring the religious and cultural demands of local peoples [11]. The weak influx of Muslims into Russian schools prompted the administration to create special schools for them (like Russian-Tatar, Russian-Bashkir, and Russian-Kazakh schools).

An attempt was made in Turkestan to use the experience of "French-native" education development in Algeria [12]. In Turkestan Russian-native schools, the indigenous children had to study with Russian children in Russian. However, unlike the foreign schools of Ilminsky, the programs of these schools kept the study of the basic principles of Islam, the Koran, the Arabic language, etc. for the "natives". 4 The first such school was opened on December 19, 1884 in Tashkent. Nalivkin V.P. and Mullah Salih-Khoja Kich-Kina-Khojin were its teachers. By next May, 38 students were studying in it. Examinations in Russian (reading and writing) and mathematics showed encouraging results at first. ${ }^{5}$ During the same year, similar schools were opened in Chinaz and Pskent (24 students) (Syrdarya region, Kuraminsky district), as well as in the Karaul volost (Kazalinsky district), where 16 Kazakh boys were recruited $[9,1885$, No. $1,20,33,43 ; 1887$, No. 18]. 116 boys were trained at four foreign schools of the Syrdarya region in 1884-1885 [9, 1887, No. 15]; this made $0.5 \%$ of the total number of Muslim students. Moreover, only in the Syrdarya region there were 53 madrassas (3020 shakirdas), 1452 maktaba elementary schools (18184 boys and 2900 girls) in 1885 [14, p. 337].

By decree of June 20, 1886, the governors-general of Turkestan could make changes to the staffing of elementary schools, "assign a teacher from the natives, or leave the school without it," open "new schools" with local funds "subject to full material support of Russian teacher", etc. at their own discretion [10, col. 592]. Soon new Russian-native schools were opened: in Ablyk (35 students), T-Lau (30), Karyze (23), Toy-Tube (22), Sairam (7), Merke (45), Sary-Chagan, Perovsky county (Syrdarya region), in Andijan (34), Namangan (6), Osh (11), Kokand, Old Margelan (Ferghana region), in Nukus, Nukus Fortification (Amudarya branch), in Kattakurgan, Jizzakh (19), Dagbit (10) (Samarkand region), Pyanjikent (9) (Bukhara emirate) [9, 1886, No. 39, 41, 48; 1887, No. 1, 2, 7, 8, 11, 13, 14, 18, 19, 29, 35] and others.

In 1886, evening classes in the Russian language of adult Muslims were opened at the Pskent school; ten listeners signed up for these courses. The following year, similar courses from parish schools were transferred to Osh, Namangan, Kokand, Kattakurgan schools, due to the "small number of students (natives - A.G.) in these courses." Russian literacy courses also opened in Tashkent; the teacher was Golubev, a graduate of the local Teacher Seminary, who was fluent in local languages [9, 1887, No. 31, 36, 47]. At the end of 1887,18 students signed up for classes. Foreign schools had an extremely simple task: "to limit teaching to the message of the basic principles of Russian literacy, that is, to accustom to correct reading, writing and numeracy within the limits strictly necessary for basic needs of foreign life." According to Governor General Rosenbach N.A. (1883-1889), "These schools should promote the lasting and final merger of all these nationalities with the great family of the indigenous Russian people in our powerful metropolis" $[15$, p. $144 ; 7$, p. 5].

However, it was not possible to provide joint education for native and Russian children, primarily because of the small number of Russian population in Turkestan. However, the attempts were made to organize such training. For example, 9 Russian children and 10 Muslims studied at the Jizzakh Russian-native school. In the Chinaz region - 19 Muslims, 4 Russian children and 1 Jewish child, in the Sairam region - 6 Muslims, 1 Russian student [9, 1887, No. 7, 18, 19]. However, these examples are the exception rather than the rule. In Russian-native schools, along with children, adults studied sometimes, which caused additional difficulties. So, if in the 1st Tashkent Russian-native school (37 children) there were 8 adults, then there were 25 adults in the 2 nd school (38 children), and 18 adults in the 3rd school (36 children) [9, 1887, No. 49].

Obviously, foreign schools lacked teachers. Only the first schools were able to provide graduates from the Tashkent seminary for teachers ${ }^{7}$. As a rule, random people worked as the teachers of the Russian language. 1 Muslim was graduated from the local seminary for teachers in 1883, and two Muslims in 1885 [9, 1885, No. 21]. To enhance the entry of Muslims into the seminary, the admission rules for them were simplified. Since 1887, it was enough to be able to read and write well in Russian, to master the first four rules of arithmetic (But there were few local young Muslims who spoke Russian well enough). The seminary program included teaching Muslim literacy, the Persian language, crafts, gardening, and aimed at training the teachers of Russian-native schools $[9$, 1887, No. 16]. The administration did not consider 
it appropriate to create a native teacher's school in Turkestan, as was done in Ufa, Simferopol, Kazan, Orsk, etc. ${ }^{8}$

Despite optimistic reports, the problems of Russian-native school planting were obvious. The "credit of trust" of local residents to the initiatives of the Russian administration was reduced in proportion to the distance from Tashkent and other centers of power. In the following years (1887-1888), the Karyz, Toytyubinsk, Nukus schools were transferred to Tashkent 9, Sairam - to Chimkent, Telausk - to Ura-Tyube fortification, Ablyks - to Turkestan [9, 1887, No. 31, 33; 1888, No. 24, 36, 37]. "The development of schools was slow". According to N.O. Rosenbach, despite significant costs - 23,000 rubles a year, "the results are negligible." With A.B. Vrevsky (1889-1898) the situation has not changed fundamentally: children "learn reluctantly, involuntarily and unsuccessfully by external compulsion" [7, p. 6, 146]. ${ }^{9}$ In 1901, 1,490 local children were studied in 45 Russian-native schools. This amounted to about $0.05 \%$ of the total number of indigenous people. Over 25 years, only 313 students completed the full course of training [17, p. 3, 7].

Along with Russian-native schools in the Turkestan Territory, the "task was to introduce the Russian language into the circle of subjects taught in Madras". In 1871, the administration created a special commission. It decided the following: a) to apply the Russian alphabet to the Uzbek language, and b) to draw up a textbook with the easiest stories using the local dialect and Russian transcription [18,27]. It was assumed that this would be the first step towards learning the Russian language. However, according to S.M. Gramenitsky, the attempts made "so far have not been successful" [17,28]. The authorities did not dare to disseminate the rules on March 26, 1870 about the compulsory creation of Russian classes in Muslim schools ${ }^{10}$, taking into account the negative experience in the Volga-Ural region.

\section{SUMMARY}

It is obvious that Russian sociocultural policy in the Turkestan region developed according to previously beaten paths. Its main goal, as in the Volga-Urals, Siberia, the Caucasus and the Crimea, was to introduce local peoples to the spiritual and cultural values prevailing in the empire. The most important acculturation trend was school policy aimed at foreigner integration into the state education system. However, as V.V. Bartold noted "the successes of the Russian school and Russian culture in general were at loss because they did not intend to inform the natives too much in their language and contribute to the consolidation of local literature and local cultural features, thus, undermining Russification". In Russian-native schools, the classes in a Russian class were exclusively in Russian. They taught only "native literacy and the foundations of Muslim faith" during the native class [19, p. 134,$173 ; 17$, pp. 12-13, 20]. This teaching system, ignoring the natural language of students ${ }^{11}$, showed very weak results. It was sharply criticized by the supporters of the Ilminsky system [13, 15, 25,26], which allowed teaching in the native language, which had some positive results in the Volga and Ural regions.

Of course, the educational policy of the administration, pursued "narrow utilitarian goals" [20, p. 82], although it was given a purely civilizational character - the inclusion of backward peoples in high European culture. Russian-native schools were oriented, first of all, to training personnel for the native administration: volost administrators, translators, foremen, and others ${ }^{12}$. They were not useful in other areas and thus were not popular. In 1909, less than 100 Russian-native schools operated in Turkestan, attended by up to 3,000 students. At the same time, 5543 Muslim maktaba (70,000 students) and 311 madrasas with 9,000 shakirdas, as well as many unregistered schools for girls and new-method schools, operated in the region [7, pp. 158-159].

\section{SUMMARY}

In general, educational policy in Turkestan was characterized by a comparative moderation of administrative pressure. This was probably due to relatively weak control over the annexed territory. During the planting of Russian-native schools, the practice of compulsory education was used to a lesser extent than in other regions. ${ }^{13}$ With regard to religious schools, authorities followed careful observation tactics. Adopted in 1906, 1907 "The rules on primary schools for foreigners living in Eastern and Southeast Russia", designed to regulate the activities of foreign schools tightly [23, 24], were not applied to the Turkestan Territory. With all the conflicting aspects, Russian educational policy played an important role in awakening the sprouts of modernization in the life of local peoples.

\section{ACKNOWLEDGEMENTS}

The work is performed according to the Russian Government Program of Competitive Growth of Kazan Federal University.

\section{REFERENCES}

1. Khalid A. The politics of Muslim cultural reform: Jadidism in Central Asia / A. Khalid. - Berkeley: University of California Press, 1998. $300 \mathrm{p}$.

2. Kotyukova T.V. Turkestan trend of the Duma policy of Russia (1905-1917) / T.V. Kotyukova. - M.: Enter-Graphics, 2008. - 201 p.

3. Gafarov A.A. Russian Muslims Lifestyle Renovation Problems in the Modernistic Literature of the Late $19^{\text {th }}$ and Early $20^{\text {th }}$ Century // Journal of Sustainable Development. - 2015. - Vol. 8, No. 7. - pp 178-184

4. Nabiyev R.A., Gafarov A.A. Phenomenon of Religious Revival in the Context of the Experience of Modernization of the Muslim Community in the Late XIX - Early XX Centuries // Journal of Sustainable Development. - 2015. - Vol. 8, No. 4. - pp. 253-259.

5. Gafarov A.A., Nabiyev R.A., Fazliev A.M., Nafikov I.Z. "Muslim matter" in the mirror of public discussion (XIX - beginning of XX century) / A.A. Gafarov, R.A. Nabiyev, A.M. Fazliev, I.Z. Nafikov // Journal of Fundamental and Applied Sciences. - 2017. - No. 9(7S). pp. 1257-1265.

6. Nazarievsky I.T. Historical outline of the legislation on primary education in Russia / Nazarevsky I.T. // Journal of public education for 1905 - Part CCCLVII. - February. - pp. 149-186.

7. Ostroumov N. Oscillations in the views on the education of natives in the Turkestan region / N.P. Ostroumov. - Tashkent, 1910. - pp. 1-6, 145-160.

8. Ostroumov N.P. Sarts. Ethnographic materials. Third supplemented version. - Tashkent, 1908. - 288 p.

9. Turkestan native newspaper. 1885. No. 1. January 12, No. 20. June 5 , No. 21. June 12, No. 28. July 31, No. 33. September 7; No. 43 November 16; 1886. No. 39. October 18, No. 48. December 20; 1887. No. 1. January 10 , No. 2. January 17 , No. 7. February 21 , No. 8 February 28, No. 11. March 21, No. 13. April 3, No. 14. April 18, No. 15. April 25, No. 16. May 2, No. 18. May 18, No. 19. May 26, No. 29 July 28, No. 31. August 14, No. 33. August 28, No. 35. September 12, No. 36. September 21, No. 47 December 5, No. 49. December 
22; 1888. No. 24. June 20, No. 26. July 5, No. 36. September 20, No. 37. September 26.

10. Collection of resolutions on the Ministry of Public Education. V. X. 1885-1888. - SPb., 1894. - 1490 col., 130 col. Eastern Outlook. 1883. No. 38. September 22.

11. Vishegorsky A. Higher Muslim education in Fez / A. Vyshegorsky // Wanderer. - 1890. - March. - pp. 481-488, April. - pp. 660-671.

12. Bobrovnikov N.A. Russian-native schools, mektebs and madrassas of Central Asia. Travel notes / N.A. Bobrovnikov. - SPb., 1913. - 90 p.

13. Syr-Daria region. Description, compiled by E. Smirnov according to official sources. - SPb., 1887. - $355 \mathrm{p}$.

14. Ostroumov N. Muslim maktabs and Russian-native schools in the Turkestan region / N.P. Ostroumov // Journal of the Ministry of Public Education. - 1906. - Part I. - January. - pp. 113-166.

15. Gramenitsky S. Essay on the development of public education in the Turkestan region / S.M. Gramenitsky. - Tashkent, 1896. - 86 p.

16. Gramenitsky S. 25th anniversary of academic affairs in the Turkestan region / S.M. Gramenitsky. - Tashkent, 1901. - 26 p. Turkestan statements. 1875. No. 16. April 22.

17. Bartold V.V. The history of the cultural life of Turkestan / V.V. Barthold. - L.: Publishing House of the Academy of Sciences of the USSR, 1927. - $256 \mathrm{p}$

18. Potanin Gr. In the yurt of the last Kyrgyz prince (From the trip to Kokchetayevsky district) / G.N. Potanin // Russian wealth. - 1896. No. 8. - pp. 60-88.

19. N.I. Ilminsky letters to the public prosecutor Konstantin Petrovich Pobedonostsev. - Kazan: Edition of the Editorial Board of the Orthodox Interlocutor, 1895. - $414 \mathrm{p}$.

20. Collection of documents and articles on the issue of the education of foreigners. - $\mathrm{SPb}$.: Publishing house of the Partnership "Public benefit", 1869. - $522 \mathrm{p}$.

21. The rules on primary schools for foreigners living in eastern and southeastern Russia. - Kazan, 1906. - 13 p.

22. The rules on primary schools for foreigners living in eastern and southeastern Russia, approved by the Ministry of Public Education on March 31, 1906 and amended on January 2, 1907 - Kazan, 1907. - 6 p.

23. Lobão, J., \& Pereira, C. Looking for Psychological Barriers in nine European Stock Market Indices. Dutch Journal of Finance and Management, 1(1), (2016). 39.

24. Oliveira, F. K. D., Oliveira, M. B. D., Gomes, A. S., \& Queiros, L. M. Identifying User Profiles from Statistical Grouping Methods. Journal of Information Systems Engineering \& Management, 3(1), (2018). 06.

25. Godino, J. D., Rivas, H., Burgos, M., \& Wilhelmi, M. R. Analysis of Didactical Trajectories in Teaching and Learning Mathematics: Overcoming Extreme Objectivist and Constructivist Positions. International Electronic Journal of Mathematics Education, 14(1), (2019). 147-161. https://doi.org/10.12973/iejme/3983

26. Novikova, I. N., Popova, L. G., Shatilova, L. M., Biryukova, E. V., Guseva, A. E., \& Khukhuni, G. T. (2018). Lexical and semantic representation of the linguistic and cultural concept "Rest" in the English, German, and Russian languages. Opción, 34(85-2), 237-256 